\title{
Volcanic Studies at Katmai
}

\author{
Panel on Volcanic Studies at Katmai \\ U.S. Geodynamics Commitize \\ Board on Earth Sciences and Resources \\ Commission on Physical Sciences, Mathematics, and Resources \\ National Research Council
}

\author{
NATIONAL ACADEMY PRESS \\ Washington, D.C. 1989
}

\section{DISCLAIMER}

This report was prepared as an account of work sponsored by an agency of the United States Government. Neither the United States Government nor any agency thereof, nor any of their employees, makes any warranty, express or implied, or assumes any legal liability o: responsibility for the accuracy, completeness, or usefulness of any information, apparatus, product, or process disclosed, or represents that its use would not infringe privately owned rights. Reference herein to any specific commercial product, process, or service by trade name, trademark, manufacturer, or otherwise does not necessarily constitute or imply its endorsement, recommendation, or favoring by the United States Government or any agency thereof. The views and opinions of authors expressed herein do not necessarily state or reflect those of the United States Government or any agency thereof. 
NOTICE: The project that is the subject of this report was approved by the Governing Board of the Nationa! Research Council, whose members are drawn from the councils of the National Academy of Sciences, the National Acadeny of Engineering, and the Institute of Medicine. The members of the committee responsible for the report were chosen for their special compeierces and with regard for appropriate balance.

This report has been reviewed by a group other than the authors according to procedures approved by a Report Review Committee consisting of members of the National Academy of Sciences, the National Academy of Engineering, and the Institute of Medicine.

The National Academy of Sciences is a private, nonprofit, self-perpetuating society of distinguished scholars engaged in scientific and engineering research, dedicated to the furtherance of science and technology and to their use for the general welfare. Upon the authority of the charter granted to it by the Congress in 1863, the Academy has a mandate that requires it to advise the federal government on scientific and technical matters. Dr. Frank Press is president of the National Academy of Sciences.

The National Academy of Engineeririg was established in 1964, under the charter of the National Academy of Sciences, as a parallel organization of outstanding engineers. It is autonomous in its administration and in the selection of its members, sharing with the National Academy of Sciences the responsibility for advising the federal government. The National Academy of Engineering also sponsors engineering programs aimed at meeting national needs, encourages education and research, and recognizes the superior achievements of engineers. Dr. Robert $M$. White is president of the National Academy of Engineering.

The Institute of Medicine was established in 1970 by the National Academy of Sciences to secure the services of eminent members of appropriate professions in the examination of policy matters pertaining to the health of the public. The Institute acts under the responsibility given to the National Academy of Sciences by its congressional charter to be an adviser to the federal government and, upon its own initiative, to identify issues of medical care, research, and education. Dr. Samuel $O$. Thier is president of the Institute of Medicine.

The National Research Council was organized by the National Academy of Sciences in 1916 to associate the broad community of science and technology with the Academy's purposes of furthering knowledge and advising the federal government. Functioning in accordance with general policies determined by the Academy, the Council has become the principal operating agency of both the National Academy of Sciences and the National Academy of Engineering in providing services to the government, the public, and the scientific and engineering communities. The Council is administered jointly by both Academies and the Institute of Medicine. Dr. Frank Press and Dr. Robert M. White are chairman and vice chairman, respectively, of the National Research Council.

Support for this project was provided by the Department of Eneigy, the National Science Foundation, and the U.S. Geological Survey.

Available from:

U.S. Geodynamics Committee

National Research Council

2101 Constitution Ave. N.W.

Washington, D.C. 20418

Printed in the United States of America 
ELBURT F. OSBORN, Pennsylvania State University, Chairman

FRANCIS R. BOYD, Geophysical Laboratory, Carnegie Institution of Washington IAN S. CARMICHAEL, University of California, Berkeley

WOLFGANG E. ELST ON, University of New Mexico

RICHARD S. FISKE, Smithscinian Institution

ALEXANDER R. McBIRNEY, University of Oregon

I. SELWYN SACKS, Department of Terrestrial Magnetism, Carnegie Institution of

Washington

Staff Consultant

WILLIAM E. BENSON 


\section{U.S. GEODYNAMICS COMMITTEE}

FRANK M. RICHTER, University of Chicago, Chairman DONALD J. DePAOLO, University of California, Berkeley

BRADFORD H. HAGER, California Institute of Technology

WILLIAM J. HINZE, Purdue University

DAVID L. JONES, University of California, Berkeley

LEIGH H. ROYDEN, Massachusetts Institute of Techrology

ROB VAN DER VOO, University of Michigan

PETER R. VAIL, Rice University

E-AN ZEN, U.S. Geological Survey

Ex officio:

ADAM M. DZIEWONSKI (Bureau Member, Inter-Union Commission on the Lithosphere)

Staff

PEMBROKE J. HART 


\section{BOARD ON EARTH SCIENCES AND RESOURCES}

WILLIAM L. FISHER, University of Texas, Austin, Co-Chairman

BRIAN J. SKINNER, Yale University, Co-Chairman

SAMUEL S. ADAMS, Colorado School of Mines

KEIITI AKI, University of Southern California

ALBERT W. BALLY, Rice University

JAMES R. BAROFFIO, Chevron USA, Inc.

SANDRA L. BLACKSTONE, University of Denver

DONALD J. DePAOLO, University of California, Berkeley

GORDON P. EATON, Iowa State University

W. GARY ERNST, Stanford University

ROBERT N. GINSBURG, University of Miami

ALEXANDER F.H. GOETZ, University of Colorado

PRISCILLA C.P. GREW, Minnesota Geological Survey

PERRY R. HAGENSTEIN, Resource Issues, Inc.

HARRISON C. JAMISON, Atlantic Richfield Exploration Company (retired)

THOMAS H. JORDAN, Massachusetts Institute of Technology

CHARLES J. MANKIN, University of Oklahoma

CAREL OTTE, JR., Unccal Corporation (retired)

FRANK M. RICHTER, University of Chicago

J.J. SIMiviONS III, Interstate Commerce Commission

STEVEN M. STANLEY, Johns Hopkins University

IRVIN L. WHITE, New York State Energy Research and Development Authority

ROBERT S. LONG, Staff Director

BETTY C. GUYOT, Staff Associate 


\section{COMMISSION ON PHYSICAL SCIENCES, MATHEMATICS, AND RESOURCES}

NORMAN HACKERMAN, Robert A. Welch Foundation, Chairman ROBERT C. BEARDSLEY, Woods Hole Oceanographic Institution B. CLARK BURCHFIEL, Massachusetts Institute of Technology GEORGE F. CARRIER, Harvard University RALPH J. CICERONE, University of California, Irvine HERBERT D. DOAN, The Dow Chemical Company (retired) PETER S. EAGLESON, Massachusetts Institute of Technology DEAN E. EASTMAN, IBM T.J. Watson Research Center MARYE ANNE FOX, University of Texas GERHART FRIEDLANDER, Brookhaven National Laboratory LAWRENCE W. FUNKHOUSER, Chevron Corporation (retired) PHILLIP A. GRIFFITHS, Duke University NEAL F. LANE, Rice University CHRISTOPHER F. McKEE, University of California, Berkeley RICHARD S. NICHOLSON, American Association for the Advancement of Science JACK E. OLIVER, Cornell University JEREMIAH P. OSTRIKER, Princeton University Observatory PHILIP A. PALMER, E.I. du Pont de Nemours \& Company FRANK L. PARKER, Vanderbilt University DENIS J. PRAGER, MacArthur Foundation DAVID M. RAUP, University of Chicago ROY F. SCHWITTERS, Superconducting Super Collider Laboratory LARRY L. SMARR, University of Illinois, Urbana-Champaign KARL K. TUREKIAN, Yale University

MYRON F. UMAN, Acting Executive Director ROBERT M. SIMON, Acting Associate Executive Director 


\section{INTRODUCTION}

The Continental Scientific Drilling Program (CSDP) is a national effort supported by the Department of Energy, the U.S. Geological Survey, and the National Science Foundation. Coordination is accomplished through the Interagency Coordinating Group, which comprises representatives of those agencies. Projects can be proposed from within or without the sponsoring agencies and from within or without the federal government.

One of the projects proposed for the CSDP consists of drilling a series of holes in Katmai National Park in Alaska to give a third dimension to the model of the 1912 eruption of Novarupta, and to investigate the processes of explosive volcanism and hydrothermal transport of metals (Eichelberger et al., 1988).

The proposal for research drilling at Katmai states that "the size, youth, elevated temperature, and simplicity of the Novarupta vent make it a truly unique scientific target." The National Park Service (NPS), which has jurisdiction, is sympathetic to aims of the study. However, because the area is both a National Park and a Wilderness Area (and therefore a sensitive area in which to drill), NPS wishes to know whether Katmai is indeed uniquely suited to the research, and has asked the Interagency Coordinating Group to support an independent assessment of this claim. NPS suggested the National Academy of Sciences as an appropriate organization to conduct the assessment.

In response, the National Research Council-the working arm of the Academyestablished, under the aegis of its U.S. Geodynamics Committee, a panel whose specific charge states: "The proposed investigation at Katmai has been extensively reviewed for scientific merit by the three sponsoring and participating agencies. Thus, the scientific merit of the proposed drilling at Katmai is not at issue. The panel will review the proposal for scientific drilling at Katmai and prepare a short report addressing the specific question of the degree to which it is essential that the drilling be conducted at Katmai as opposed to volcanic areas elsewhere in the world."

In addressing its charge, the panel has drawn on the personal knowledge of its members, a selective review of the literature, a search of the data bank of the Smithsonian Institution, and personal contacts with other voicanologists, notably from Hawaii, Japan, England, and France.

Because aspects such as scientific merit, cost, and environmental considerations are being reviewed by other groups, they are outside this panel's purview. That the panel does not comment on them implies neither a favorable nor an unfavorable opinion of the project as a whole. 


\section{KATMAI VOLCANO}

\section{General Features}

On June 6,1912, the Alaskan Peninsula was rocked by a large explosive eruption comprising about $15 \mathrm{~km}^{3}$ of magma that expanded to twice that volume, producing $15 \mathrm{~km}^{3}$ of airborne ash plus a like amount in an ash-flow sheet. This sheet filled two existing valleys up to $200 \mathrm{~m}$ deep and created what is now the Valley of Ten Thousand Smokes (Figure 1). The vent area, named Novarupta, was at a distance of 5 to $17 \mathrm{~km}$ from four pre-existing volcanic edifices and was blasted through virtually unaltered marine sedimentary rocks. The magma chamber that fed the eruptions seems to have been some $10 \mathrm{~km}$ distant under Mount Katmai, whose summit collapsed after the eruption to form a caldera $3 \mathrm{~km}$ in diameter. Novarupta itself subsided along concentric fractures; it is uncertain whether this moderate subsidence was caused wholly by compaction (Hildreth and Fierstein, 1986) or whether some collapse may have been involved. The eruptive sequence ended with the extrusion of Novarupta Dome and the intrusion of a presumed laccolithic body to form a domelike feature known as the Turtle (Figure 2).

Chemically, the 1912 eruptive products ranged from rhyolite to andesites, with rhyolite and dacite predominating.

\section{Advantages of Katmai}

The general objectives of the proposal are to test the three-dimensional models for intrusion, eruption, cooling, alteration, and transport of metals in a wellpreserved vent and ash flow (Figure 3). The attractive features of Katmai for the study are well-stated in the proposal. We summarize them as follows:

1. Size. The $15 \mathrm{~km}^{3}$ of erupted magma makes the 1912 event one of the larger silicic eruptions of historic times. It is large enough to be catastrophic, but small enough to be typical of many explosive eruptions and also small enough to be studied by the proposed drilling. The ash flow is large enough to have a welded interior, probably the only recent flow in the world with welding.

2. Youth. A deposit the size of the Novarupta ash flow and vent almost certainly retains substantial residual heat after only 77 years, and retrograde hydrothermal alteration has not yet overprinted primary lithology.

3. Simplicity. The 1912 eruption was a single discrete event; Novarupta was blasted through previously unaltered Jurassic sedimentary rocks. Thus there is no overprinting of earlier volcanic events by successive episodes of eruption or hydrothermal alteration. Moreover, the country rock will be readily distinguishable from the 1912 volcanic rock in drill samples. Because there has been no major summit collapse at Novarupta, the structure of the vent area is relatively uncomplicated and could be more easily interpreted from drill cores.

4. Shallowness. Preliminary geophysical studies suggest that the vent bottoms between 1 and $2 \mathrm{~km}$. Thus the various compositional components of the ash flow should have identifiable counterparts in the cores from the vent. 


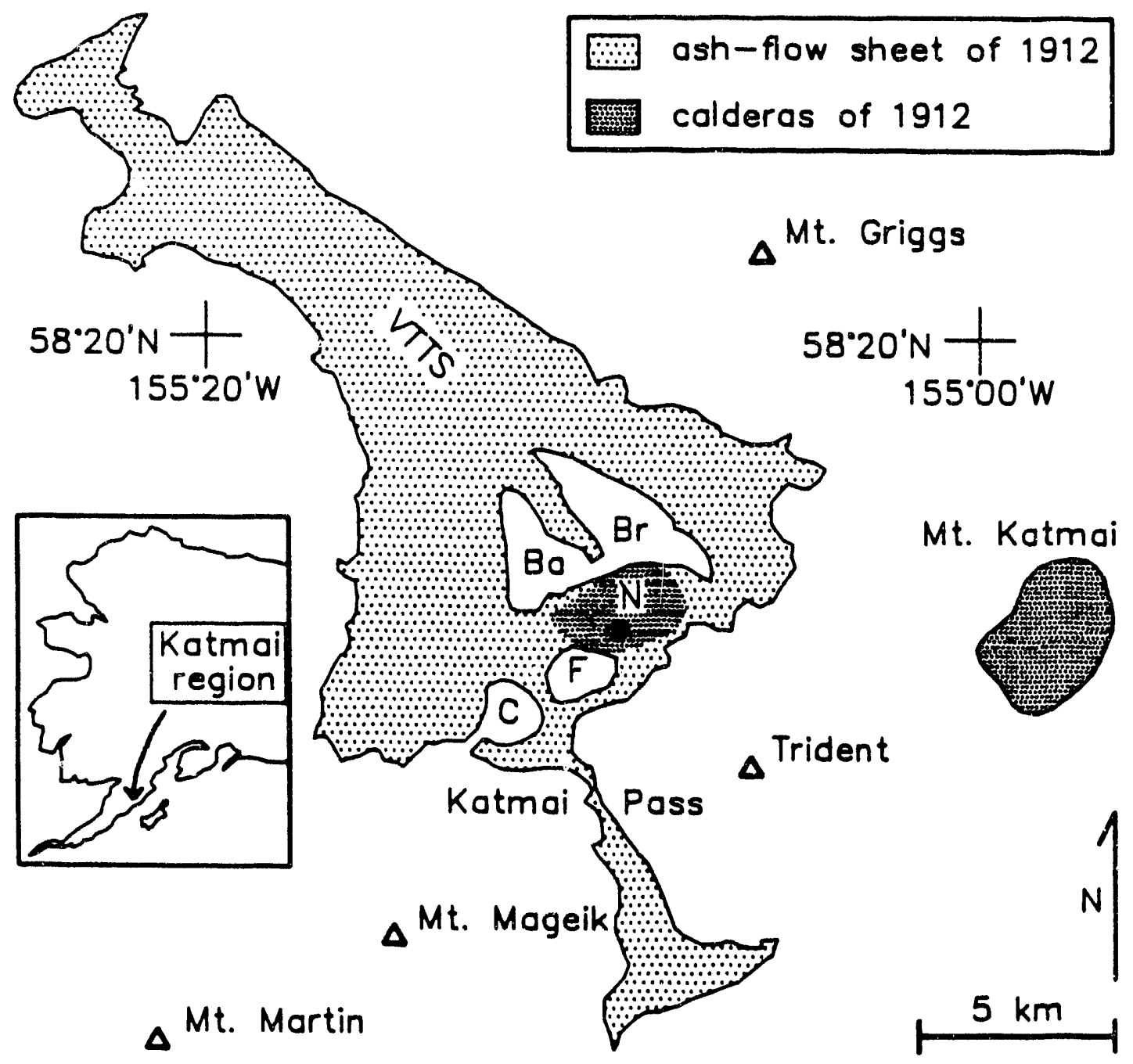

FIGURE 1 Map of the Valley of Ten Thousand Smokes, showing locations of the ashflow sheet, Novarupta and Mount Katmai calderas, and neighboring volcanoes. Inset shows location. Abbreviations: Ba, Baked Mountain; Br, Broken Mountain; C, Mountain Cerberus; F, Falling Mountain; N, Novarupta. (After Hildreth, 1983; reproduced from Eichelberger et al., 1988.)

5. Known Transport and Deposition of Metals. That metals were being transported by hydrothermal processes at Katmai has been well documented by earlier workers (e.g., Zies 1929, Griggs 1918, and Fenner 1 150). These processes are probably continuing, and the area has been neither degraded by erosion nor complicated by other events. 


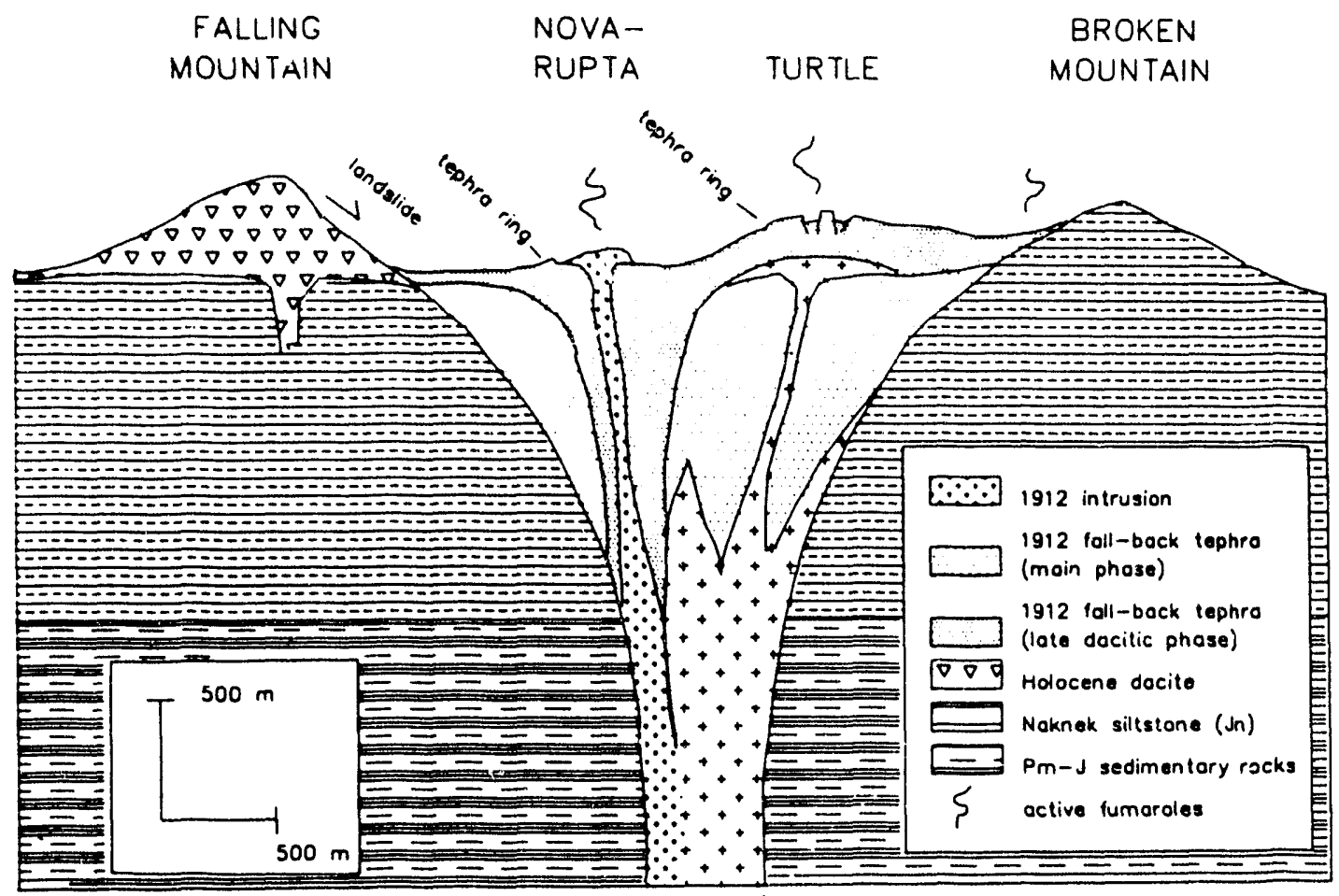

FIGURE 2 Preferred model for the 1912 vent. Consistent with this model, the lithic ejecta consist dominantly of Naknek Formation, indicating that the excavated volume is within 1 $\mathrm{km}$ of the surface. This large flared funnel is presumed to have formed early in the eruption during the rhyolitic Plinian A phase and/or during ash-flow sheet emplacement. Vent fill may consist of fluidized-bed material that never reached the surface as well as fallback. At some unknown depth, there must be a downward transition to the unfragmented intrusive equivalents of the pyroclastic units. The vent-filling tephra was intruded by intact magma, which fed Novarupta Dome and possibly a buried dome of shallow intrusion beneath the Turtle. Nested within the large vent, and containing the Novarupta feeder, is the much smaller vent for the late dacitic Plinian phase of the eruption. (After Eichelberger et al., 1988.)

\section{Disadvantages of Katmai}

Few things are perfect; no volcanic area is or will ever be ideal for every aspect of research. The less favorable aspects of Katmai are as follows:

1. Location of the Magma Chamber. The fact that Mount Katmai itself underwent a caldera-forming collapse while Novarupta remained almost intact strongly suggests that the magma reservoir is or was beneath Mount Katmai with a lateral feeder to Novarupta. Therefore the magma chamber itself is not a feasible target of the proposed study. 


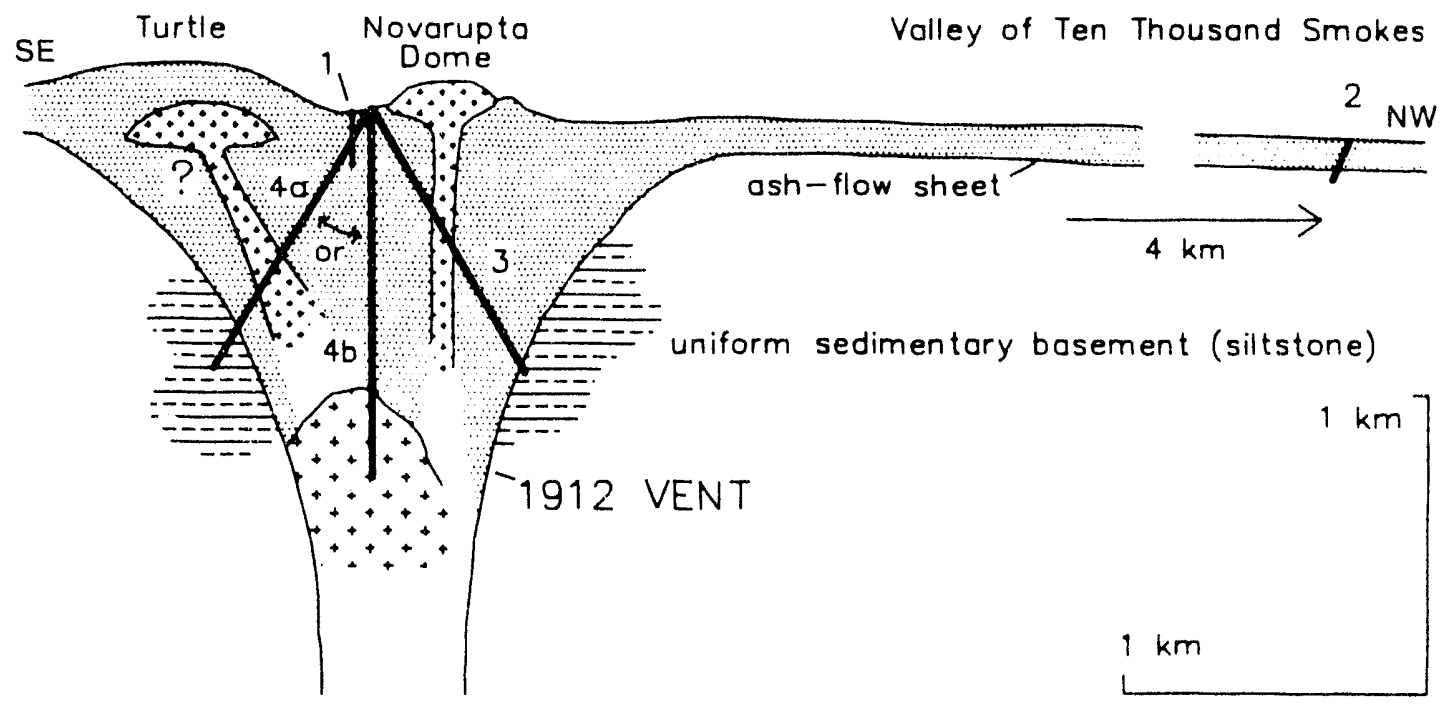

FIGURE 3 Schematic cross section of the vent and ash-flow sheet along a curved line containing the two drilling sites and the Turtle, illustrating geological objectives of the proposed holes. (After Eichelberger et al., 1988.)

2. Lack of Direct Observation and Study Prior to 1912. The Novarupta event was seen only at a distance. There was no eyewitness close enough to describe the eruptive stages that could thus be tied to the stratigraphy of the flow or the deposits in the vent. Nor was there any prior geophysical record of the area.

\section{COMPARISON WITH OTHER AREAS}

The drilling targets at Novarupta are the complete penetration of a young welded ash flow and the sampling of a simple young conduit to identify eruptive mechanisms and thermal behavior.

Therefore, in looking at possible alternative sites for the research, the panel has concentrated on relatively recent silicic eruptions with an explosivity index of 5 or more (Table 1) and has considered (1) size, (2) presence of an ash flow, (3) evidence of hydrothermal activity, and (4) simplicity.

Silicic volcanoes punctuate the landscape in many parts of the world, but most of these can be dismissed rather quickly as rival targets. For example, Santorini and Krakatau have collapsed summits that are partly submerged; Mont Pelée and Soufrière of St. Vincent are too small; Vesuvius and Aetna are too complex, etc. More suitable alternative sites and areas include the following:

1. Quizapu (Cerro Azul) in the Chilean Andes, which erupted in 1932. As described by Hildreth and Drake (1988), Quizapu erupted about $5 \mathrm{~km}^{3}$ of magma $\left(=18 \mathrm{~km}^{3}\right.$ of pumice) and has an ash flow. The flow, however, has a volume of only $0.01 \mathrm{~km}^{3}$ (minute as compared to Katmai), hac almost certainly cooled to ambient 
temperature, and is unlikely to have a welded zone. Moreover, Quizapu is a flank vent on a complex strato-volcano.

2. Cosigüina in Nicaragua erupted in 1835 and has an ash flow. But, even ignoring the political situation, drilling logistics would be very difficult, the eruption has not been well studied, and the eruption is from a complex strato-volcano.

3. Tambora in Lesser Sunda erupted in $\mathbf{1 8 1 2}$ with the largest explosivity index $(\mathrm{VEI}=7)$ in the last 1000 years. But Tambora is now cool, has had extensive caldera collapse, and is a complex volcanic edifice.

4. East African Rift valley area.* Silicic volcanics have been erupted in the area around Lake Naivasha, the youngest consisting of 400-year-old domes and viscous trachytic flows. But the flows are older than the ash and have not come from the same vents, and the vents are all in pre-existing volcanics whose stratigraphy is very complex.

5. White Island, Taupo Volcanic Zone, New Zealand. A group of investigators has recently proposed a $600-\mathrm{m}$ hole in White Island, a volcano at the northeast end of the Taupo Volcanic Zone. For the last 150 years, White Island has been the zone's most active vent (including several explosive events in the past 20 years). White Island has an extensive hydrothermal system, the operation of which is the chief target of the proposed drilling.

In comparison with the eruption at Katmai, White Island eruptions are small, and there are no welded ash flows; the vent itself is very complex and overprinted by many eruptions and recurrent hydrothermal activity. This is not to belittle the value of the proposed drilling. It would enhance our understanding of hydrothermal systems both as sources of geothermal power and as makers of metal ores. It would expand on but not substitute for the Katmai project. Indeed, if both Katmai and White Island are drilled, the value of the hydrothermal studies at both would be enhanced.

6. Mount St. Helens. Of all alternate sites, Mount St. Helens is probably the most attractive.

The possible advantages are as follows:

- Detailed documentation (geological and geophysical) both during and after the 1980 event.

- Pre-eruption geological and geophysical studies.

- Stratigraphy of the pyroclastics can be tied directly to eruption stages.

- A known active hydrothermal system.

- The magma chamber is directly below and could be investigated.

The disadvantages are as follows:

- $\quad$ Size-it is less than 5 percent of the size of Novarupta.

- Ash is a mixture of 1980 and earlier material (though they may be chemically distinct) and not welded.

- Complexity of the volcano.

*Information on East African Rift valley is from R.A. MacDonald, University of Lancaster. 
TABLE 1 Global Volcanic Eruptions of VEI 5 to 7, 1000 A.D. to 1980 A.D.

\begin{tabular}{|c|c|c|c|}
\hline $\begin{array}{l}\text { Date of } \\
\text { Eruption }\end{array}$ & Volcano Name (location) & $\begin{array}{l}\text { Volcanic } \\
\text { Explosivity } \\
\text { Index (VEI) }\end{array}$ & $\begin{array}{l}\text { Eruption from } \\
\text { Pre-existing } \\
\text { Volcano? }\end{array}$ \\
\hline C $1015 q$ & Billy Mitchell (Bougainville-SW) & 5 & yes \\
\hline C $1020 ?$ & Tarawera (New Zealand) & 5 & yes \\
\hline 1104 & Hekla (Iceland-S) & 5 & yes \\
\hline $1108 ?$ & Asama (Honshu-Japan) & $5 ?$ & yes \\
\hline 1362 & Oraefajokull (Iceland-S) & 6 & yes \\
\hline $1477 ?$ & Kverkfjoll (Iceiand-S) & 5 & yes \\
\hline D 1480 & Mouwt St. Yelens (U.S.-Washington) & 5 & yes \\
\hline C $1580 p$ & Billy Mitchell (Bougainville-SW) & 6 & yes \\
\hline $1 C 10$ & Awu (Sangihe Is.-Indonesia) & $5 ?$ & yes \\
\hline $16: 40$ & Komaga-Take (Hokkaido-Japan) & 5 & yes \\
\hline$C: 660 p$ & Long Island (New Guinea-NE of) & 6 & yes \\
\hline 1663 & Usu (Hokkaido-Japan) & 5 & yes \\
\hline 1667 & Tarumai (Hokkaido-Japan) & 5 & yes \\
\hline 1707 & Fuji (Honshu-Japan) & 5 & yes \\
\hline 1739 & Tarumai (Hokkaido-Japan) & 5 & yes \\
\hline 1755 & Katla (Iceland-S) & 5 & yes \\
\hline 1812 & Tambora (Lesser Sunda Is.) & 7 & yes \\
\hline 1822 & Galunggung (Java) & 5 & yes \\
\hline 1835 & Cosigiuina (Nicaragua) & 5 & yes \\
\hline 1854 & Sheveluch (Kamchatka) & 5 & yes \\
\hline 1875 & Askja (Iceland-N) & 5 & yes \\
\hline 1883 & Krakatau (Indonesia) & 6 & yes \\
\hline 1886 & Tarawera (New Zealand) & 5 & yes \\
\hline 1902 & Santa Maria (Guatemala) & 6 & yes \\
\hline 1907 & Ksudach (Kamchatka) & 5 & yes \\
\hline 1912 & Novarupta (Alaska Peninsula) & 6 & no \\
\hline 1932 & Cerro Azul [Quizapu] (Chile-C) & 6 & yes \\
\hline 1955 & Bezymianny (Kamchatka) & 5 & yes \\
\hline 1980 & Mount St. Helens (U.S.-Washington) & 5 & yes \\
\hline
\end{tabular}

${ }^{\mathrm{a}} \mathrm{C}$ designates carbon-14 date; $\mathrm{D}$, dendrochronology (tree ring) date; $q, \pm 25$-year uncertainty; $p, \pm 20$-year uncertainty.

SOURCE: Data from Simkin et al. (1981). 
- As a National Monument, Mount St. Helens is subject to the same constraints on potentially disruptive activities as Novarupta.

As can be seen from these examples of alternative targets, most possible sites fail to match Katmai in at least two of its advantageous features. Most importantly, all fail the test of simplicity. Table 1, derived from the data bank of the Smithsonian Institution, lists all known large explosive eruptions (VEI $=5$ or more) since 1000 A.D. and shows that only Novarupta came from a pristine vent. All others came from and through pre-existing volcanic structures. Therefore, only Katmai can claim freedom from overprinting and can demonstrate that all the effects of the eruption and thermal activity derive from a single event.

\section{SUMMARY AND CONCLUSION}

The Novarupta vent area at Katmai offers five advantageous features: (1) size $\left(15 \mathrm{~km}^{3}\right)$; (2) youth (not modified by erosion and still hot); (3) documented ongoing hydrothermal activity including metal transport; (4) shallow depths to critical horizons; and (5) simplicity (eruption through unaltered sediments and apparently simple subsidence of the summit).

Of these factors, simplicity is of overriding importance, because it ensures that all chemical alterations are the result of one event acting on unaltered nonvolcanic country rock and single-event eruptive rocks and because it will enable a more definitive interpretation of the vent composition and structure.

A canvass of other explosive volcanoes of the world shows none that can match all the features of Novarupta. Most important, no other recent eruption has blasted a vent through previously unaltered rock.

The panel therefore concludes that the authors of the proposal are correct in maintaining that the Katmai area is uniquely suited to the proposed research and is an excellent target "for a research drilling investigation of silicic magmatic processes."

\section{SELECTED REFERENCES}

Eichelberger, J.C., Hildreth, W., and Papike, J.J., 1988. Direct observation of a young igneous system: a science plan for research drilling at Katmai, Alaska. Unpublished. $218 \mathrm{pp}$.

Fenner, C.N., 1950. The chemical kinetics of the Katmai eruption, Am. J. Sci, 248, 593-627.

Gigenbach, W.F., Hedengurst, J.W., Houghton, B.F., Otway, P.M., and Allis, R.G., 1989. Research drilling into the volcanic hydrothermal system on White Island, New Zealand, EOS, vol. 70, pp. 98-108.

Griggs, R.F., 1918. The eruption of Katmai, Nature, 101, pp. 497-509.

Hildreth, W., 1983. The compositionally zoned eruption of 1912 in the Valley of Ten Thousand Smokes, Katmai National Park, Alaska, J. Volcanol. Geotherm. Res., vol. 18 , pp. 1-56. 
Hildreth, W., and Fierstein, J., 1986. Near-vent ejecta around Novarupta, eruption of 1912, Katmai National Park, Alaska (abs.), EOS, vol. 67, no. 44, p. 1246.

Hildreth, W. and Drake, R.E., 1988. The eruption of Volcan Quizapu, Chilean Andes (abs.), Geol. Soc. Amer. 1988 Meeting, Abstracts with Program, p. A7.

McClelland, L., Simkin, T., Summers, M., Nielsen, E., and Stein, T.C., 1989. Global Volcanism 1975-1985: The First Decade of Reports from the Smithsonian Institution's Scientific Event Alert Network (SEAN), Prentice-Hall/American Geophysical Union, 655 pp.

Simkin, T., Siebert, L., McClelland, L., Bridge, D., Newhall, C., and Latter, J.H., 1981. Volcanoes of the World, Hutchinson-Ross Publ. Co., Stroudsburg, Pennsylvania, $232 \mathrm{pp}$.

Simkin, T., and Siebert, L., 1984. Explosive eruptions in time and space, in Explosive Volcanism: Inception, Evolution, and Hazards, National Academy Press, Washington, D.C., pp. 110-121.

Zies, E.G., 1929. The Valley of Ten Thousand Smokes: I. The fumarolic incrustations and their bearing on ore deposition. II. The acid gases contributed to the sea during volcanic activity, Nat. Geogr. Soc. Contr. Tech. Papers, Katmai Ser. 4, pp. 1-79. 

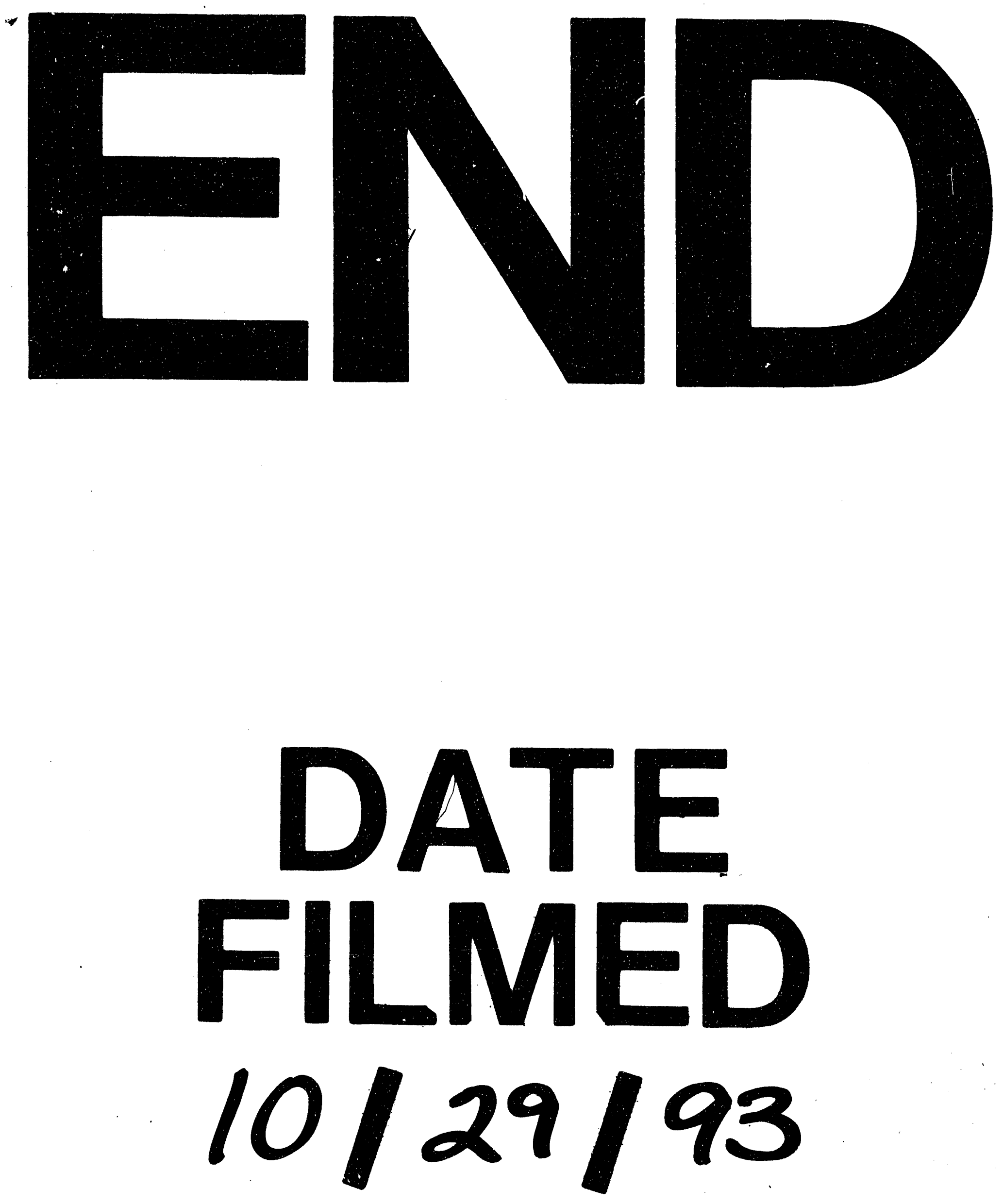

1 
